\title{
Intra-Industry Trade and Labour-Market Adjustment: A Reassessment Using Data on Individual Workers
}

\author{
Marius Brülhart, Robert J. R. Elliott, and Joanne Lindley \\ University of Lausanne; University of Birmingham; University of Sheffield
}

\begin{abstract}
We re-examine the relationship between intra-industry trade and labour reallocation, using individual-level data on manufacturing worker moves in the United Kingdom. The contribution of this analysis is twofold. First, we estimate the impact of intra-industry trade on worker moves between occupations as well as between industries. Second, we run individual-level regressions that allow us to control for worker heterogeneity. Our results suggest that intra-industry trade does have the stipulated attenuating effect on worker moves, both between occupations and between industries, but that this effect is relatively small compared to other determinants of labour reallocation. JEL no. F1, J62, C25

Keywords: Intra-industry trade; worker mobility; labour-market adjustment
\end{abstract}

\section{Introduction}

Measures of intra-industry trade (IIT) continue to be popular as first-pass proxies for the adjustment effects of trade expansion. According to the frequently invoked Smooth Adjustment Hypothesis (SAH), the factor-market adjustment pressure induced by increased trade exposure is negatively related to the share of IIT in the expanded trade flow.

A number of empirical studies linking measures of labour-market adjustment to trade patterns have recently found evidence in support of the $\mathrm{SAH}$. This research has focused on industry-level measures and determinants of adjustment. In this paper we employ individual-level data on manufacturing employees in the United Kingdom to construct "distance" mea-

Remark: We thank an anonymous referee and participants at the 2004 conference of the European Trade Study Group in Nottingham for helpful suggestions, and Vicente Blanes and Richard Upward for their help with data concordances. Marius Brülhart gratefully acknowledges financial support from the Swiss National Science Foundation (Grant 61265970). Please address correspondence to Marius Brülhart, Département d'économétrie et économie politique (DEEP), HEC, Université de Lausanne, 1015 Lausanne, Switzerland; e-mail: Marius.Brulhart@unil.ch 
sures of worker moves across industries and occupations. This allows us to explore whether IIT relates systematically to worker reallocations not only across sectors but also across occupations, and to control for individuallevel characteristics that might be correlated with sector-level variables and thus have biased previous estimates.

Our results indicate that IIT, particularly when quantified in the "marginal" sense, relates negatively to both the sectoral and the occupational distance of worker moves. This is consistent with the SAH. The result is robust to the inclusion of individual-level controls. We conclude, therefore, that the SAH retains empirical support and that the intra- or inter-industry nature of trade expansion does affect, albeit by a smaller magnitude than other determinants, the nature of labour reallocation.

The paper is organized as follows. In Section 2, we review the background literature. Section 3 outlines our empirical approach and describes the data. The estimation results are presented in Section 4. Section 5 concludes.

\section{Literature Background}

\subsection{The Smooth Adjustment Hypothesis}

We study the relation between IIT and job moves, taking the latter as an indicator of labour-market adjustment costs. The proposition that IIT entails lower costs of factor-market adjustment than inter-industry trade, originally suggested by Balassa (1966) and further developed in the influential monographs on IIT by Grubel and Lloyd (1975) and Greenaway and Milner (1986), has become widely accepted by international economists.

The intuitive power of the $\mathrm{SAH}$ is undisputed, although the precise meaning of the IIT-adjustment hypothesis remains somewhat cloudy, and the two underlying concepts, trade-induced adjustment costs and IIT, have been subject to differing implicit interpretations. We therefore briefly elucidate the three key components of the SAH: trade as an exogenous variable, adjustment costs, and IIT.

There are two principal conceptions of trade as a source of adjustment. In partial-equilibrium, small open economy (SOE) models, adjustment is traditionally analysed in the context of a change in world market prices. Such price changes are exogenous to the $\mathrm{SOE}$, and can originate from a multitude of sources, such as changes in demand, factor endowments, transport systems, technology or trade policies. Such changes can be labelled "trade 
induced", since they would not affect the SOE in autarky. The second concept of trade as a source of adjustment centres on changes in trade costs, holding everything else constant in multi-country general-equilibrium models. Under that definition, trade-induced adjustment is sparked by a change in the level of barriers to international trade. Hence, domestic adjustment is trade induced if it is caused by either a reduction in trade barriers, holding everything else constant; or by any relevant changes in foreign markets, holding trade costs constant (i.e. zero). Real economies, of course, are subject to continuous changes in demand and production structures. Trade liberalization occurs simultaneously with other changes (notably in technology), and the two types of trade-induced adjustment, while separable in theory, are difficult to disentangle empirically from each other and from other determinants of structural change. Applied work therefore commonly considers as "trade induced" any change in the domestic economy that can be traced to a change in trade volumes or prices vis-à-vis the rest of the world, based on the (admittedly strong) assumption that trade patterns are an unbiased measure of exogenous changes in trading conditions.

Adjustment costs can also be grouped into two categories. First, they can arise in perfectly competitive markets with flexible prices. If factors are subject to any degree of heterogeneity and product specificity, then tradeinduced reallocation will inevitably divert resources to make the transition possible. Hence, production will occur inside the long-run production possibility frontier for the duration of adjustment, as resources are used to re-train, move and match labour, and to adapt the capital stock. Temporary factor-price disparities are needed to incite resource use on such "adjustment services", which in turn may significantly reduce the net gains from trade liberalization (although the net effect on welfare remains positive). ${ }^{1}$ Furthermore, if transitional wage and income disparities go uncompensated, trade liberalization produces net losers with incentives to oppose the policy reform in the first place. The second class of adjustment costs arises in the presence of market imperfections. The most commonly analysed imperfection is that of downwardly rigid nominal wages. Under such a configuration, adjustment costs might outweigh the gains from trade, and hence trade liberalization could in theory be Pareto inferior. ${ }^{2}$ The net effect on welfare depends on the magnitude of adjustment costs and trade gains

\footnotetext{
1 See Davidson and Matusz $(2001,2004)$ and Bacchetta and Jansen (2003) for recent assessments of trade-induced adjustment costs.

2 See Brecher and Choudhri (1994).
} 
as well as on the social discount rate. The challenge for applied research is to obtain a good measure of adjustment costs. Most empirical research on trade and adjustment therefore relies on measures of factor reallocation that plausibly correlate with adjustment costs. ${ }^{3}$

Turning to the definition of IIT, the most frequently employed measure is the Grubel-Lloyd (GL) index:

$$
I I T_{i t}=1-\frac{\left|M_{i t}-X_{i t}\right|}{\left(M_{i t}+X_{i t}\right)}
$$

where $M$ stands for imports in a particular industry $i, X$ represents corresponding exports, and $t$ is the reference year. The value of this index ranges between 0 and 1, inclusive, and increases in the proportion of IIT. It has become standard practice not to adjust the index for overall trade imbalance, since an unbalanced trade account can well be compatible with overall balance of payments equilibrium. ${ }^{4}$

The GL index is a static measure, in the sense that it captures IIT for one particular year. However, adjustment is a dynamic phenomenon. Hamilton and Kniest (1991) suggested that for applied research on tradeinduced adjustment on should instead employ measures of "marginal" IIT (MIIT). They argued that the observation of a high proportion of IIT in one particular time period does not justify a priori any prediction of the likely pattern of change in trade flows. Even an observed increase in static IIT levels between two periods $\left(G L_{t}-G L_{t-1}>0\right)$ could "hide" a very uneven change in trade flows, concomitant with inter- rather than intraindustry adjustment. MIIT, however, denotes parallel increases or decreases of imports and exports in an industry. Matched changes of sectoral trade volumes are expected to have a neutral effect on employment. For example, if industry $i$ imports expand, domestic jobs may be threatened in that industry,

3 Attempts to measure adjustment directly include Jacobson et al. (1993), who have estimated an individual's average lifetime loss from displacement to be around $\$ 80,000$, although the evidence on the extent of wage loss varies considerably across countries and the length of previous job tenure of the displaced workers. At the industry level, de Melo and Tarr (1990) calculated the ratio of the present discounted value of the benefits of liberalization to the costs of worker displacement and estimated that the gains from liberalization were approximately $\$ 28$ for every dollar of cost. In a similar study for the UK footwear industry, Takacs and Winters (1991) have estimated that the abolition of quantitative restrictions can generate more than $\$ 80$ of gain for every dollar of cost. For a survey, see Matusz and Tarr (2000).

4 A comprehensive survey of this and related issues with relevance to the interpretation of GL indexes can be found in Greenaway and Milner (1986). 
but if industry $i$ exports expand by a comparable amount, this may offset lost market share in the domestic market and yield a zero net change in the industry's domestic employment. ${ }^{5}$ A number of MIIT measures have since been developed. Probably the most straightforward of these measures is a transposition of the GL index to first differences of sectoral trade flows:

$$
M I I T_{i t}=1-\frac{\left|\Delta X_{i t}-\Delta M_{i t}\right|}{\left|\Delta X_{i t}\right|+\left|\Delta M_{i t}\right|},
$$

where $\Delta$ stands for the difference between years $t$ and $t-T$ (Brülhart 1994). This index, like the GL index, varies between 0 and 1 , where 0 indicates marginal trade in the particular industry to be completely of the inter-industry type, and 1 represents marginal trade to be entirely of the intra-industry type. The MIIT index shares most of the statistical properties of the GL index. ${ }^{6}$

\subsection{Empirical Research on IIT and Adjustment}

The SAH can be thought of as the conjunction of two empirical relationships. One is a relationship between IIT and some concept of the "distance" a worker moves: the higher the proportion of new trade that is IIT, the smaller is the difference between the representative worker's job now compared to their job prior to the trade expansion. At one extreme, where all trade expansion is IIT, workers may not be displaced, and if they are displaced they will move within their industry and potentially even within their firm - a relatively small distance. At the other extreme, where trade expansion is entirely inter-industry, displaced workers in contracting industries will have to seek reemployment in a different (expanding) industry—a relatively large distance.

The second relationship that makes up the SAH is between the distance of job moves and adjustment costs: it posits that the distance of job moves is positively correlated with the cost of adjustment.

This study assesses the validity of the first relationship that makes up the SAH, i.e. the link between IIT and worker moves. Before we can consider

\footnotetext{
5 This conjecture evidently only holds if other relevant variables are held constant. Lovely and Nelson $(2000,2002)$ have shown that, in general equilibrium, MIIT can be associated with inter-industry reallocation of factors if productivity is also allowed to change.

6 See Brülhart (2002) and Azhar and Elliott (2004) for discussions of the properties of this and alterative MIIT measures.
} 
such an investigation as a test of the $\mathrm{SAH}$, we have to ascertain that the second relationship, between the distance of worker moves and adjustment costs, in fact holds. There is compelling empirical evidence to support this claim. Using a variety of methods, a number of researchers have found that it is costlier for workers to move across industries (or occupations) instead of switching job within industries (or occupations). ${ }^{7}$

It thus appears reasonable to consider an estimation of the relationship between IIT and the distance of worker moves as a test of the SAH. However, ours is not the first paper to estimate this relationship. Some previous studies have regressed worker moves on a vector of determinants that includes measures of trade exposure. ${ }^{8}$ These studies were mostly supportive of the SAH: (M)IIT was found to correlate positively with "low-distance" worker moves.

We take another look at this question for two principal reasons. First, previous studies measured the distance of job moves as the frequency of inter-industry moves relative to intra-industry moves. This may not be the most relevant definition of distance if the aim is to proxy for adjustment costs. There is indeed evidence that many workers who move across industries in fact remain in the exact same occupation (think of secretaries or accountants), and that the average adjustment cost is higher for occupation moves than for industry moves. ${ }^{9}$ We therefore estimate the impact of IIT not only on the "sectoral distance" of worker moves but also on the "occupational distance". ${ }^{10}$

Second, existing tests of the link between IIT and worker moves are almost exclusively based on sectorally aggregated data. ${ }^{11}$ Sector-level studies could be subject to estimation bias as they cannot control for individual-

7 See, e.g., Greenaway et al. (2000) and Haynes et al. (2002) for the United Kingdom, and Fallick (1993), Kletzer (1996), Neal (1995) and Shin (1997) for the United States.

8 See Greenaway et al. (2002), Brülhart and Elliott (2002) and Elliott and Lindley (2006a) for the United Kingdom; Andersson et al. (2000) for Sweden; and Brülhart (2000) for Ireland.

9 See Haynes et al. (2002).

10 Greenaway et al. (2002) report average shares of inter-industry, inter-occupation and inter-region worker moves separately for high- and low-IIT sectors. Their bivariate analysis suggests no attenuating effect of IIT on sectoral or occupational adjustment. However, they do not consider occupation moves in their multivariate analysis or in conjunction with MIIT measures.

11 Greenaway et al. (2002) draw on individual-level data but estimate their model on sector-level aggregates. Elliott and Lindley (2006a) estimate the determinants of sector moves via a multinomial logit model that includes IIT measures. They do not consider occupational moves. 
level characteristics that may be correlated with certain industry-level variables. Even in the absence of aggregation bias, using disaggregated data will enhance the efficiency of estimation. Drawing on individual-level data from the British Labour Force Survey, we therefore combine industrylevel determinants of worker moves (including IIT and MIIT) with worker characteristics that are typically considered in the empirical labour literature.

\section{Empirical Model and Data}

\subsection{Regression Specification}

We measure the distance of job moves in two dimensions, sectoral and occupational. In both cases, we take statistical classifications and posit that the distance of a job move increases the higher the level of statistical aggregation of the sectors or occupations between which a worker moves. For example, a worker who switches from a job in one 3-digit industry to a job in another 3-digit industry but still within the same 2-digit industry is assumed to have moved a smaller distance than a worker who switches from one 2-digit industry to another. Since the statistical classifications that organize our data distinguish several aggregation levels, we can in principle distinguish several distance levels. This notwithstanding, statistical aggregation levels provide us with a rough ordering at best, and there is no way of measuring distances in a cardinal sense. We therefore use the standard between-versus-within sector distinction for the industrylevel estimations. In individual-level estimation, however, we can explicitly account for the ordinal differences among job moves via ordered logit estimation.

We first run industry-level regressions. This is to check for consistency with previous research while including occupation moves as a complementary measure of labour-market adjustment. In the absence of a well-specified theoretical base for model selection, we include a set of standard explanatory variables plus various measures of (M)IIT. ${ }^{12}$ Specifically, we estimate

\footnotetext{
12 For analyses using similar specifications, see Andersson et al. (2000), Brülhart (2000), Brülhart and Elliott (2002), Elliott and Lindley (2006a) and Greenaway et al. (2002). Further motivation for the set of control variables used here can be found in those papers.
} 
the following model:

$$
\begin{aligned}
\text { WORKERMOVES }_{i t}^{D}= & \beta_{0}+\beta_{1} \times\left\{\begin{array}{l}
\text { MIIT_T } \\
I I T_{i t}
\end{array}\right\}+\beta_{2} \text { TRADE }_{i t} \\
& +\beta_{3} \text { FIRMNO }_{i t}+\beta_{4} W A G E_{i t} \\
& +\beta_{5} \text { DDEM }_{i t}+\lambda_{t}+u_{i t},
\end{aligned}
$$

where

- WORKERMOVES $S_{i t}^{D}$ denotes the (logistically transformed) share of the total number of sample workers in industry $i$ in year $t$ who move industry or occupation at statistical aggregation level $D$ between year $t$ and year $t+1$,

- MIIT_T $T_{i t}$ denotes the MIIT index as defined in (2), calculated for the period between $t-T$ and $t$,

- IIT denotes the GL index as defined in (1),

- TRADE denotes trade exposure, defined as the sum of sectoral imports and exports divided by sector value added,

- FIRMNO denotes the number of firms divided by sector value added,

- WAGE denotes the average wage,

- DDEM denotes the change in sector apparent consumption between year $t-1$ and $t$,

- $\lambda$ is a year fixed effect, and

- $u$ is a stochastic error term.

The dependent variable, WORKERMOVES, comes in two forms: moves between industries and moves between occupations. In the industry dimension, $D$ represents the sectoral distance of a worker move, which ranges from moving firm within the same SIC 3-digit industry to moving between different SIC (UK Standard Industrial Classification) 2-digit industries. ${ }^{13}$ In the occupation dimension, $D$ represents the occupational distance of a worker move, which ranges from moving between 3-digit SOC (UK Standard Occupational Classification) occupations to moving between 1-digit occupations. The variable is logistically transformed so as to be symmetric and unbounded. ${ }^{14}$

The expected coefficients on TRADE and FIRMNO are positive: both variables can be read as proxies for the intensity of product-market competition in a sector, and intensified competition is associated with higher worker

13 For a description of the statistical classifications see Section 3.2 and the Appendix.

14 Specifically, if $S$ denotes the share of movers, then WORKERMOVES $=\ln (S /[1-S])$. 
turnover, across both industries and occupations (Andersson et al. 2000). Conversely, we expect WAGE to have an attenuating influence on industry moves (although not necessarily on occupation moves), since workers' resistance to moving to a different industry is likely to be higher if they originate in a high-wage industry, ceteris paribus. Finally, we expect a negative impact on industry moves (although not necessarily on occupation moves) of DDEM: industries with expanding domestic demand force fewer worker moves than industries with contracting domestic demand.

The main focus of our interest is $\beta_{1}$, which, for consistency with the SAH, would be expected to be significantly negative. Moreover, the measurement literature would suggest $\beta_{1}$ to be less significant (or not at all) when the regressor takes the form of the static IIT index rather than a measure of MIIT. Furthermore, the structure of trade patterns can be expected to matter more for the labour markets of sectors that are highly trade oriented. Therefore, we augment model (3) with an interaction term between (M)IIT and TRADE. The SAH leads us to expect a negative coefficient on this interaction: the more exposed to trade a certain sector, the stronger the job-reallocation attenuating effect of (M)IIT.

Our regression model implies specific dynamics. According to equation (3), one-year job moves react to product-market conditions in the base year, and to MIIT over a period that ends in the base year. Worker flows are thus modelled as reacting to product-market changes with a lag. Space constraints do not allow us to report large sets of regressions with different dynamic specifications. However, the timing structure used here has been found to perform best in previous research, and exploratory regressions on the data used here confirmed these results. ${ }^{15}$ One variation on the baseline dynamics that we do report is to estimate model (3) on the industry-level data with all variables expressed as two-year averages. This might remove some randomness inherent in yearly data while retaining the relatively short-term time horizon over which the model provides the best fit with the data.

For estimation on individual-level data, model (3) requires two major modifications. First, the dependent variable becomes discrete. In the dichotomous version, a worker either moves between $D$-digit sectors/occupations or she does not. Assuming an appropriately distributed disturbance term, this calls for logit or probit estimation. In the polychotomous ver-

15 See Brülhart (2000). These results (as well as all other estimations mentioned in this paper but not shown explicitly) are available from the authors on request. 
sion, we rank classes of workers' moves according to how distant a sector or occupation they have moved to, where distance in turn is defined by the statistical aggregation level. The natural estimator for this model is ordered logit or probit. ${ }^{16}$

Second, individual-level data allow us to control for worker characteristics. We retain the standard variables from the labour literature, representing age, gender, size of firm of base-year employment, marital status, home ownership, nationality, educational attainment and geographic region (see, e.g. Neal 1995 and Dolton and Kidd 1998). Some obvious priors can be formulated: both industry and occupation moves are likely to become less probable with age (as job specific sunk capital accumulates), industry moves are less probable the larger the employing firm (since the firm itself offers greater career prospects), and, to the extent that they correlate with geographic moves, both industry and occupation moves are less probable for individuals with dependent children and/or own their own homes.

\subsection{Data}

For the labour-market information, we use individual-level data for manufacturing employees from the Spring quarters of the British Quarterly Labour Force Survey (QLFS) for 1992 to 2000 and annual data from the Labour Force Survey (LFS) 1986 to $1991 .{ }^{17}$ In each year, individuals are asked questions about their circumstances twelve months prior to the survey. Included are questions on economic activity such as employment status, industry of employment and occupational status. This information enables us to construct our "distance" variables by industry and occupation. The data also contain information on individuals' characteristics such as age, sex, martial status, region of residence and educational qualifications. Precise definitions and summary statistics of our individual-level variables are given in the Appendix.

Crucial to our understanding of job moves being thought of in terms of the "distance" moved, is the use of statistical classifications as natural boundaries. Throughout this paper we employ industry and occupation

\footnotetext{
16 For both the polychotomous and the dichotomous models, we report logit results. Probit estimates are qualitatively identical.

17 The QLFS is a pseudo panel that follows the same individuals for five consecutive quarters. We consider only workers who were employed in the manufacturing sector both at the time of data collection and a year prior to that time. Hence, movers into and out of manufacturing, or into and out of employment, are not considered.
} 
definitions based on the UK Standard Industrial Classification 1980 (SIC80) and Standard Occupational Classification 1990 (SOC90) respectively. ${ }^{18}$ For the manufacturing sector, our data cover 22 SIC 2-digit sectors, approximately 103 3-digit sectors and 1814 -digit sectors. The SOC classification distinguishes nine 1-digit, 77 2-digit and 359 3-digit occupations respectively.

For the industry-level information, we draw on 3-digit SIC80 data from the Annual Business Enquiry (1995-2000) and Business Monitor series (1986-1994), and on trade data from the OECD. ${ }^{19}$ The individual-level data from the LFS are used to construct the industry-level dependent variables: the number of individuals moving $D$-digit industries or occupations is computed for the 3-digit industry level to provide a measure of the proportion of workers in an industry that have moved at different aggregation levels.

\section{Results}

\subsection{Sector versus Occupation Moves}

One of our two main contributions is to relate trade patterns to occupation moves as well as to sector moves. Before estimating equation (3) for those two adjustment dimensions, it is interesting to explore the direct relationship between them. The previous literature which estimated the impact of (M)IIT on sectoral labour reallocations implicitly assumed that sector and occupation moves are significantly positively correlated. This conjecture is to some extent confirmed by our data: the Spearman correlation coefficient between our sectoral and occupational "distance" variables (INDMOVDIST and FIRMMOVDIST, see Table A1) for the 181,850 individuals in our sample equals 0.41 , which is statistically significant at the 0.01

\footnotetext{
18 For a full listing of SIC80 and SOC90 codes at all aggregation levels see the LFS user manual at www.data-archive.ac.uk/doc/4998/mrdoc/pdf/classifications.pdf. The 19942000 industry data are concorded from SIC92 to SIC80 employing a concordance used in Greenaway et al. (2000).

19 Trade data were concorded from 5-digit SITC Rev. 2 (Standard International Trade Classification) to 3-digit $\operatorname{SIC}(80)$ using a concordance that is available from the authors upon request. Import and export deflators were used to deflate the trade data while the GDP deflator was used to deflate the industry level data. For our individual-level regressions, the 3-digit industry and trade data are matched to the 3-digit industry of each worker twelve months prior to the time of the survey. See the Appendix for further details.
} 
per cent confidence level. On average, sectoral and occupational moves do tend to be positively related.

The correlation, however, is far from perfect. This is evident in Table 1, which cross-tabulates industry and occupation moves. We observe, on the one hand, that, of the 5.1 per cent of sample workers who changed occupation, only 2.2 per cent (i.e. less than half) also changed firm. ${ }^{20}$ On the other hand, it is easy to see from Table 1 that, of the 5.2 per cent of sample workers who changed firm, only 2.2 per cent (i.e. again less than half) also changed occupation. Hence, a significant number of occupational changes occur within firms, and equally significant number of industry changes imply no occupational change. We therefore estimate equation (3) for both sectoral and occupational moves, as a robustness check for prior work that was confined to the sectoral dimension of labour adjustment.

Table 1: Cross-Tabulation of Year-on-Year Worker Moves

\begin{tabular}{|c|c|c|c|c|c|}
\hline $\begin{array}{l}\text { Industry } \\
\text { moves }\end{array}$ & None & $\begin{array}{c}\text { 3-digit } \\
\text { SOC }\end{array}$ & $\begin{array}{l}\text { 2-digit } \\
\text { SOC }\end{array}$ & $\begin{array}{l}\text { 1-digit } \\
\text { SOC }\end{array}$ & Total \\
\hline None & $\begin{array}{c}167,155 \\
91.92\end{array}$ & $\begin{array}{l}343 \\
0.19\end{array}$ & $\begin{array}{c}1,242 \\
0.68\end{array}$ & $\begin{array}{c}3,653 \\
2.01\end{array}$ & $\begin{array}{c}172,393 \\
94.8\end{array}$ \\
\hline Firm & $\begin{array}{c}2,769 \\
1.52\end{array}$ & $\begin{array}{c}63 \\
0.03\end{array}$ & $\begin{array}{l}134 \\
0.07\end{array}$ & $\begin{array}{l}476 \\
0.26\end{array}$ & $\begin{array}{c}3,442 \\
1.89\end{array}$ \\
\hline 4-digit SIC & $\begin{array}{l}259 \\
0.14\end{array}$ & $\begin{array}{c}15 \\
0.01\end{array}$ & $\begin{array}{c}22 \\
0.01\end{array}$ & $\begin{array}{c}68 \\
0.04\end{array}$ & $\begin{array}{l}364 \\
0.20\end{array}$ \\
\hline 3-digit SIC & $\begin{array}{l}438 \\
0.24\end{array}$ & $\begin{array}{c}36 \\
0.02\end{array}$ & $\begin{array}{c}77 \\
0.04\end{array}$ & $\begin{array}{l}205 \\
0.11\end{array}$ & $\begin{array}{l}756 \\
0.42\end{array}$ \\
\hline 2-digit SIC & $\begin{array}{c}1,943 \\
1.07\end{array}$ & $\begin{array}{l}176 \\
0.10\end{array}$ & $\begin{array}{l}891 \\
0.49\end{array}$ & $\begin{array}{c}1,882 \\
1.03\end{array}$ & $\begin{array}{c}4,892 \\
2.69\end{array}$ \\
\hline Total & $\begin{array}{c}172,564 \\
94.9\end{array}$ & $\begin{array}{c}633 \\
0.35\end{array}$ & $\begin{array}{c}2,366 \\
1.30\end{array}$ & $\begin{array}{c}6,284 \\
3.46\end{array}$ & $\begin{array}{c}181,847 \\
100\end{array}$ \\
\hline
\end{tabular}

Notes: Numbers of workers above, percentages in italics. Columns correspond to values of OCCMOVDIST. Rows correspond to values of INDMOVDIST (see Table A1). Number of SIC(80) manufacturing industries in underlying classification: 2-digit: 22; 3-digit: 103; 4-digit: 181. Number of SOC occupations in underlying classification: 1-digit: 9; 2-digit: 77; 3-digit: 359 .

20 Note that in our data, changing industry necessarily implies changing firm. See Elliott and Lindley (2006b) for further discussion on sector and occupation moves at a disaggregated level. 


\subsection{Industry-Level Regressions}

Our industry-level estimations of equation (3) are presented in Tables 2 and 3. Table 2 reports findings for industry moves. We draw the job-move boundary alternatively at the SIC 2-digit level (columns 1 to 9) and at the SIC 3-digit level (columns 10 to 18): for the construction of the dependent variable, anybody who moved 2-digit sectors (or 3-digit sectors respectively) between $t$ and $t+1$ is considered a mover, while anybody else is considered a "stayer".

Our results are reassuringly robust across specifications and in line with our priors as well as with the findings of previous papers. The estimated coefficient on MIIT and IIT is always negative, as predicted by the SAH. In all runs without interaction terms, the coefficients on MIIT indexes are statistically significantly different from zero, while, in the two-year specifications, the coefficients on the IIT index are not statistically significant. Furthermore, the standardized (beta) coefficients on MIIT are generally larger than those of the coefficients on IIT. Finally, the interaction effects with sectoral trade orientation, reported in columns 7 to 9 and 16 to 18 , are negative, large and statistically highly significant throughout. The SAH thus passes with flying colours.

As for the control variables, the coefficients on FIRMNO, TRADE and WAGE have the expected signs throughout and are statistically different from zero in a majority of cases. The average wage turns out to be the most influential variable both in term of coefficient size and of statistical significance: high sectoral wages clearly deter outward worker mobility. Only the positive coefficients on DDEM in the one-year runs (columns 1 to 3 and 10 to 12) do not conform to our prior; their magnitude, however, is comparatively small.

Table 3 presents regression results with the same right-hand-side specifications as those shown in Table 2, but with the dependent variable now measuring occupation moves. The boundary between movers and stayers is drawn alternatively at the SOC 1-digit level (columns 1 to 9) and at the SOC 3-digit level (columns 10 to 18).

Again, we find consistently negative and predominantly statistically significant coefficient estimates on the (M)IIT indexes, as implied by the SAH. The estimated coefficients on the control variables also conform with our priors. In these regressions, however, the MIIT measure does not systematically "outperform" the static IIT index. Nonetheless, the estimation suggests that (M)IIT also matters in terms of occupational adjustment: high 
Review of World Economics 2006, Vol. 142 (3)

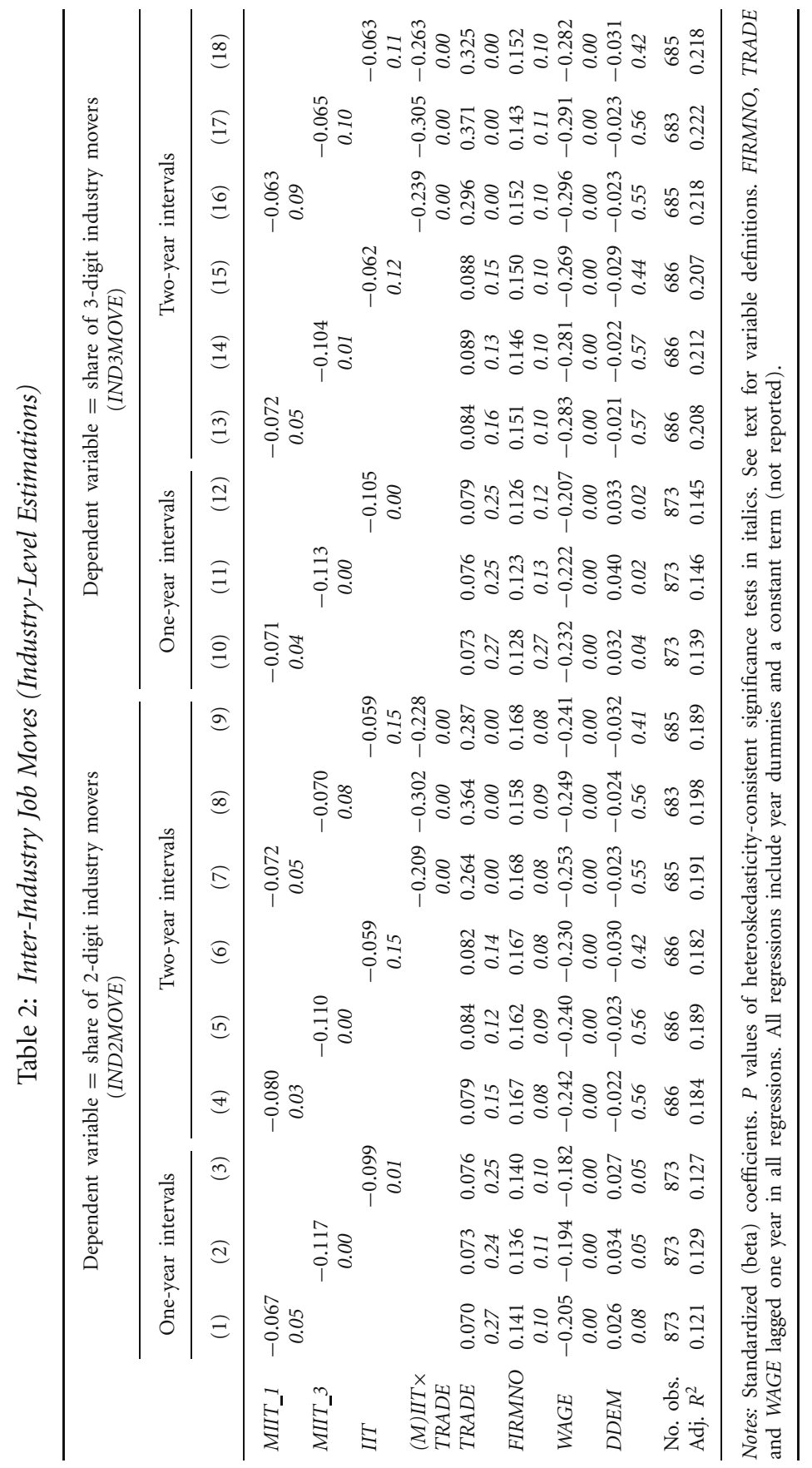


Brülhart/Elliott/Lindley: Intra-Industry Trade

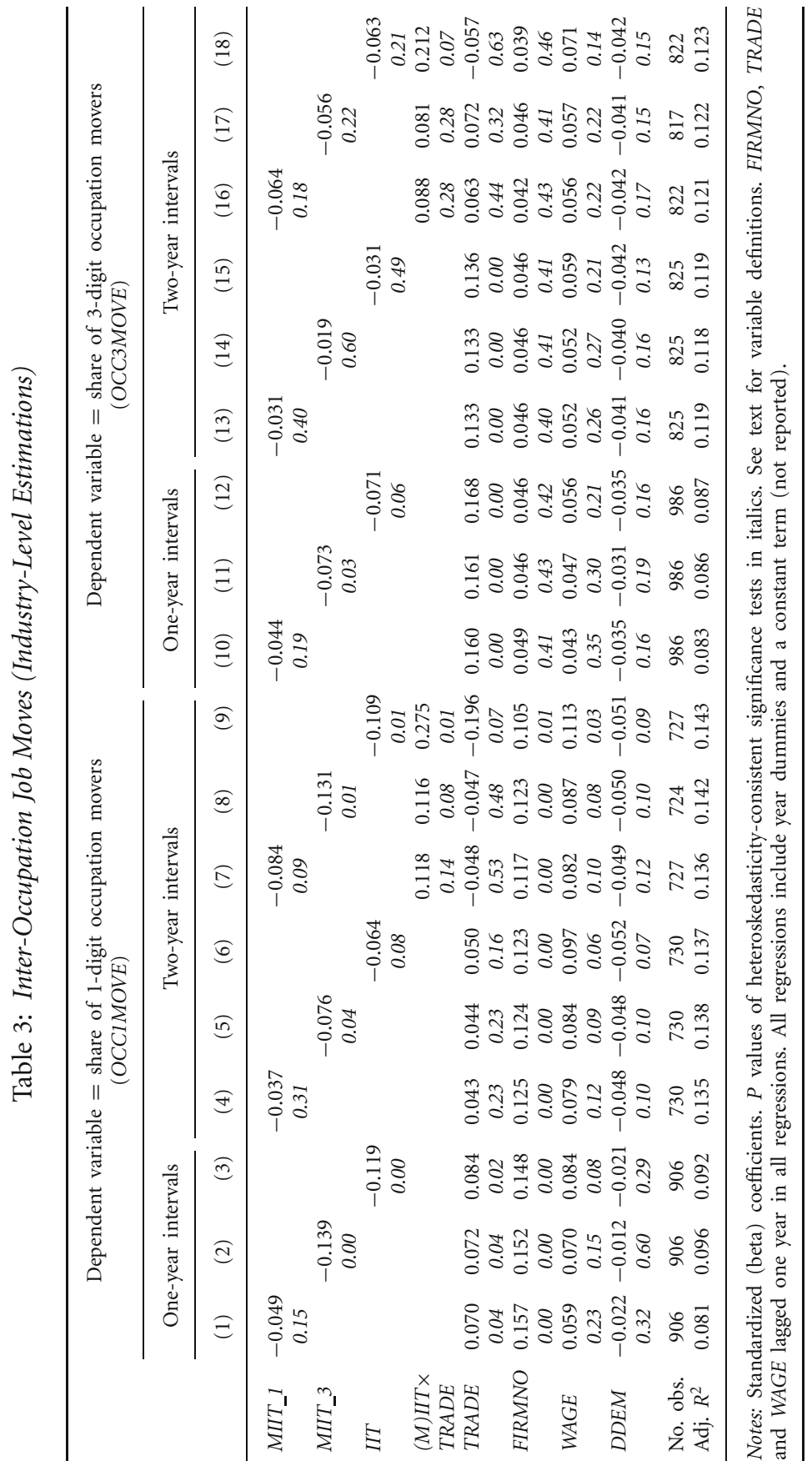


(M)IIT implies a relatively smaller frequency of inter-occupation worker moves. Given the finding of Haynes et al. (2002) that occupational moves on average imply greater adjustment costs than sector moves, this could be considered weighty evidence in support of the SAH.

Yet, our estimates in Table 3 on the interaction effects between (M)IIT and trade exposure sound a note of caution. These coefficients are estimated to be positive, which runs diametrically against the logic of the $\mathrm{SAH}$, as it implies that the labour-market effect of (M)IIT becomes smaller the stronger is the trade orientation of a particular sector. Furthermore, the main effects on MIIT and IIT in the specifications with interaction terms are estimated as significantly negative in both Table 2 and Table 3. This implies that (M)IIT significantly reduces worker moves when trade exposure is in fact zero: an evidently nonsensical result. What could explain these estimates? Given the degree of arbitrariness in model selection and dynamic structure, one could think of many specification and measurement issues that might distort our findings. We investigate one particular suspicion: omitted variable bias stemming from the aggregation of individual worker moves to the sector level. In the following, we therefore estimate the model on individual-level data, which allows us to control for within-industry heterogeneity. By doing this, we are of course only controlling for one of the potential misspecification problems. However, we view this as a step in the right direction from the existing literature, and we believe that the use of individual-level data to control for within-industry heterogeneity may also help allay other measurement problems. Nonetheless, there remains considerable scope for future work to improve the model in other directions, be it via more precise measures of adjustment costs, or via more rigorous modelling of causal relationships.

\subsection{Individual-Level Regressions}

Analogous to our presentation of industry-level estimations, we report regression results on individual-level data in two tables. Table 4 shows estimates for the individual-level model of industry moves, while Table 5 presents the corresponding results for occupation moves. In both tables, the parameters are estimated through an ordered logit model (where the regressand is a distance ranking of worker moves) and through a simple logit model (where the regressand is a dummy variable for movers and stayers). Given the additional reality-check this implies for the SAH, we now 
Table 4: Inter-Industry Job Moves (Individual-Level Estimations)

\begin{tabular}{|c|c|c|c|c|c|c|}
\hline & \multicolumn{3}{|c|}{$\begin{array}{c}\text { Dep. var. }=\text { "distance" of industry } \\
\text { move (INDMOVDIST) }\end{array}$} & \multicolumn{3}{|c|}{$\begin{array}{l}\text { Dep. var. = dummy for firm } \\
\text { move (FIRMMOVDUM) }\end{array}$} \\
\hline & \multicolumn{3}{|c|}{ Ordered logit } & \multicolumn{3}{|c|}{ Logit } \\
\hline & (1) & (2) & $(3)$ & $(4)$ & $(5)$ & (6) \\
\hline \multicolumn{7}{|c|}{ Individual-level variables (continuous): } \\
\hline$A G E$ & $\begin{array}{c}-0.554 \\
0.00\end{array}$ & $\begin{array}{c}-0.555 \\
0.00\end{array}$ & $\begin{array}{c}-0.557 \\
0.00\end{array}$ & $\begin{array}{c}-0.518 \\
0.00\end{array}$ & $\begin{array}{c}-0.519 \\
0.00\end{array}$ & $\begin{array}{c}-0.521 \\
0.00\end{array}$ \\
\hline AGE SQUARED & $\begin{array}{c}-0.141 \\
0.25\end{array}$ & $\begin{array}{c}-0.141 \\
0.25\end{array}$ & $\begin{array}{c}-0.138 \\
0.26\end{array}$ & $\begin{array}{c}-0.175 \\
0.15\end{array}$ & $\begin{array}{c}-0.174 \\
0.15\end{array}$ & $\begin{array}{c}-0.173 \\
0.16\end{array}$ \\
\hline \multicolumn{7}{|c|}{ Individual-level variables (binary): } \\
\hline FEMALE & $\begin{array}{c}-0.097 \\
0.21\end{array}$ & $\begin{array}{c}-0.095 \\
0.22\end{array}$ & $\begin{array}{c}-0.093 \\
0.22\end{array}$ & $\begin{array}{c}-0.102 \\
0.19\end{array}$ & $\begin{array}{c}-0.100 \\
0.20\end{array}$ & $\begin{array}{c}-0.098 \\
0.21\end{array}$ \\
\hline BIGFIRM & $\begin{array}{c}-0.580 \\
0.00\end{array}$ & $\begin{array}{c}-0.580 \\
0.00\end{array}$ & $\begin{array}{c}-0.579 \\
0.00\end{array}$ & $\begin{array}{c}-0.600 \\
0.00\end{array}$ & $\begin{array}{c}-0.600 \\
0.00\end{array}$ & $\begin{array}{c}-0.599 \\
0.00\end{array}$ \\
\hline PARTTIME & $\begin{array}{c}-0.569 \\
0.00\end{array}$ & $\begin{array}{c}-0.569 \\
0.00\end{array}$ & $\begin{array}{c}-0.570 \\
0.00\end{array}$ & $\begin{array}{c}-0.572 \\
0.00\end{array}$ & $\begin{array}{c}-0.573 \\
0.00\end{array}$ & $\begin{array}{c}-0.574 \\
0.00\end{array}$ \\
\hline MARRIED & $\begin{array}{c}0.168 \\
0.00\end{array}$ & $\begin{array}{c}0.168 \\
0.00\end{array}$ & $\begin{array}{c}0.168 \\
0.00\end{array}$ & $\begin{array}{c}0.168 \\
0.00\end{array}$ & $\begin{array}{c}0.168 \\
0.00\end{array}$ & $\begin{array}{c}0.168 \\
0.00\end{array}$ \\
\hline HOMEOWNER & $\begin{array}{c}-0.295 \\
0.00\end{array}$ & $\begin{array}{c}-0.294 \\
0.00\end{array}$ & $\begin{array}{c}-0.295 \\
0.00\end{array}$ & $\begin{array}{c}-0.291 \\
0.00\end{array}$ & $\begin{array}{c}-0.291 \\
0.00\end{array}$ & $\begin{array}{c}-0.291 \\
0.00\end{array}$ \\
\hline FOREIGNBORN & $\begin{array}{c}0.052 \\
0.51\end{array}$ & $\begin{array}{c}0.052 \\
0.50\end{array}$ & $\begin{array}{c}0.053 \\
0.50\end{array}$ & $\begin{array}{c}0.061 \\
0.44\end{array}$ & $\begin{array}{c}0.062 \\
0.44\end{array}$ & $\begin{array}{c}0.063 \\
0.43\end{array}$ \\
\hline HIGHEREDUC & $\begin{array}{c}0.252 \\
0.00\end{array}$ & $\begin{array}{c}0.254 \\
0.00\end{array}$ & $\begin{array}{c}0.253 \\
0.00\end{array}$ & $\begin{array}{c}0.263 \\
0.00\end{array}$ & $\begin{array}{c}0.265 \\
0.00\end{array}$ & $\begin{array}{c}0.265 \\
0.00\end{array}$ \\
\hline NOQUALIF & $\begin{array}{c}-0.256 \\
0.00\end{array}$ & $\begin{array}{c}-0.257 \\
0.00\end{array}$ & $\begin{array}{c}-0.255 \\
0.00\end{array}$ & $\begin{array}{c}-0.262 \\
0.00\end{array}$ & $\begin{array}{c}-0.262 \\
0.00\end{array}$ & $\begin{array}{c}-0.261 \\
0.00\end{array}$ \\
\hline Industry-level vari & & & & & & \\
\hline FIRMNO & $\begin{array}{c}0.026 \\
0.11\end{array}$ & $\begin{array}{c}0.027 \\
0.10\end{array}$ & $\begin{array}{c}0.027 \\
0.10\end{array}$ & $\begin{array}{c}0.025 \\
0.13\end{array}$ & $\begin{array}{c}0.026 \\
0.12\end{array}$ & $\begin{array}{c}0.027 \\
0.13\end{array}$ \\
\hline WAGE & $\begin{array}{c}-0.193 \\
0.00\end{array}$ & $\begin{array}{c}-0.191 \\
0.00\end{array}$ & $\begin{array}{c}-0.196 \\
0.00\end{array}$ & $\begin{array}{c}-0.195 \\
0.00\end{array}$ & $\begin{array}{c}-0.193 \\
0.00\end{array}$ & $\begin{array}{c}-0.198 \\
0.00\end{array}$ \\
\hline DDEM & $\begin{array}{c}0.018 \\
0.12\end{array}$ & $\begin{array}{c}0.019 \\
0.11\end{array}$ & $\begin{array}{c}0.019 \\
0.13\end{array}$ & $\begin{array}{c}0.019 \\
0.11\end{array}$ & $\begin{array}{c}0.019 \\
0.10\end{array}$ & $\begin{array}{c}0.019 \\
0.12\end{array}$ \\
\hline TRADE & $\begin{array}{c}0.041 \\
0.25\end{array}$ & $\begin{array}{l}0.026 \\
0.02\end{array}$ & $\begin{array}{c}-0.089 \\
0.67\end{array}$ & $\begin{array}{c}0.043 \\
0.26\end{array}$ & $\begin{array}{c}0.029 \\
0.02\end{array}$ & $\begin{array}{c}-0.119 \\
0.58\end{array}$ \\
\hline MIIT_1 & $\begin{array}{c}0.027 \\
0.30\end{array}$ & & & $\begin{array}{c}0.029 \\
0.27\end{array}$ & & \\
\hline MIIT_3 & & $\begin{array}{c}0.010 \\
0.71\end{array}$ & & & $\begin{array}{c}0.011 \\
0.66\end{array}$ & \\
\hline IIT & & & $\begin{array}{c}0.019 \\
0.55\end{array}$ & & & $\begin{array}{c}0.016 \\
0.61\end{array}$ \\
\hline$(M) I I T \times T R A D E$ & $\begin{array}{c}-0.037 \\
0.23\end{array}$ & $\begin{array}{c}-0.026 \\
0.00\end{array}$ & $\begin{array}{c}0.093 \\
0.65\end{array}$ & $\begin{array}{c}-0.038 \\
0.23\end{array}$ & $\begin{array}{c}-0.028 \\
0.00\end{array}$ & $\begin{array}{c}0.124 \\
0.55\end{array}$ \\
\hline Pseudo $R^{2}$ & 0.0319 & 0.0319 & 0.0319 & 0.0402 & 0.402 & 0.0402 \\
\hline
\end{tabular}

Notes: 136,380 observations. Standardized (beta) coefficients for industry-level and continuous individual-level variables; raw coefficients divided by regression standard error for binary individual-level variables. $P$ values of significance tests based on industry-level clustered standard errors in italics. See text for variable definitions. Industry-level variables, BIGFIRM and PARTTIME lagged one period. All regressions include year dummies and region dummies (North, Yorkshire, North West, East Midlands, West Midlands, East Anglia, South West, South East, Wales, Scotland, Northern Ireland). 
Table 5: Inter-Industry Job Moves (Individual-Level Estimations)

\begin{tabular}{|c|c|c|c|c|c|c|}
\hline & \multicolumn{3}{|c|}{$\begin{array}{c}\text { Dep. var. }=\text { "distance" of occupation } \\
\text { move (OCCMOVDIST) }\end{array}$} & \multicolumn{3}{|c|}{$\begin{array}{l}\text { Dep. var. = dummy for 3-digit occu- } \\
\text { pation move (OCC3MOVDUM) }\end{array}$} \\
\hline & \multicolumn{3}{|c|}{ Ordered logit } & \multicolumn{3}{|c|}{ Logit } \\
\hline & (1) & $(2)$ & (3) & (4) & $(5)$ & (6) \\
\hline \multicolumn{7}{|c|}{ Individual-level variables (continuous): } \\
\hline$A G E$ & $\begin{array}{c}-0.221 \\
0.09\end{array}$ & $\begin{array}{c}-0.222 \\
0.09\end{array}$ & $\begin{array}{c}-0.223 \\
0.09\end{array}$ & $\begin{array}{c}-0.226 \\
0.08\end{array}$ & $\begin{array}{c}-0.226 \\
0.08\end{array}$ & $\begin{array}{c}-0.228 \\
0.08\end{array}$ \\
\hline AGE SQUARED & $\begin{array}{c}-0.474 \\
0.00\end{array}$ & $\begin{array}{c}-0.473 \\
0.00\end{array}$ & $\begin{array}{c}-0.471 \\
0.00\end{array}$ & $\begin{array}{c}-0.470 \\
0.00\end{array}$ & $\begin{array}{c}-0.469 \\
0.00\end{array}$ & $\begin{array}{c}-0.467 \\
0.00\end{array}$ \\
\hline \multicolumn{7}{|c|}{ Individual-level variables (binary): } \\
\hline FEMALE & $\begin{array}{c}0.028 \\
0.60\end{array}$ & $\begin{array}{c}0.031 \\
0.56\end{array}$ & $\begin{array}{c}0.030 \\
0.57\end{array}$ & $\begin{array}{c}0.035 \\
0.51\end{array}$ & $\begin{array}{c}0.038 \\
0.47\end{array}$ & $\begin{array}{c}0.037 \\
0.48\end{array}$ \\
\hline BIGFIRM & $\begin{array}{c}0.161 \\
0.01\end{array}$ & $\begin{array}{c}0.163 \\
0.01\end{array}$ & $\begin{array}{c}0.161 \\
0.01\end{array}$ & $\begin{array}{c}0.166 \\
0.01\end{array}$ & $\begin{array}{c}0.167 \\
0.01\end{array}$ & $\begin{array}{c}0.165 \\
0.00\end{array}$ \\
\hline PARTTIME & $\begin{array}{c}-0.298 \\
0.00\end{array}$ & $\begin{array}{c}-0.300 \\
0.00\end{array}$ & $\begin{array}{c}-0.299 \\
0.00\end{array}$ & $\begin{array}{c}-0.305 \\
0.00\end{array}$ & $\begin{array}{c}-0.307 \\
0.00\end{array}$ & $\begin{array}{c}-0.306 \\
0.00\end{array}$ \\
\hline MARRIED & $\begin{array}{c}0.122 \\
0.01\end{array}$ & $\begin{array}{c}0.122 \\
0.01\end{array}$ & $\begin{array}{c}0.122 \\
0.01\end{array}$ & $\begin{array}{c}0.123 \\
0.01\end{array}$ & $\begin{array}{c}0.123 \\
0.01\end{array}$ & $\begin{array}{c}0.123 \\
0.01\end{array}$ \\
\hline HOMEOWNER & $\begin{array}{c}-0.242 \\
0.00\end{array}$ & $\begin{array}{c}-0.242 \\
0.00\end{array}$ & $\begin{array}{c}-0.243 \\
0.00\end{array}$ & $\begin{array}{c}-0.248 \\
0.00\end{array}$ & $\begin{array}{c}-0.247 \\
0.00\end{array}$ & $\begin{array}{c}-0.248 \\
0.00\end{array}$ \\
\hline FOREIGNBORN & $\begin{array}{c}-0.215 \\
0.10\end{array}$ & $\begin{array}{c}-0.213 \\
0.10\end{array}$ & $\begin{array}{c}-0.214 \\
0.10\end{array}$ & $\begin{array}{c}-0.213 \\
0.10\end{array}$ & $\begin{array}{c}-0.211 \\
0.10\end{array}$ & $\begin{array}{c}-0.212 \\
0.10\end{array}$ \\
\hline HIGHEREDUC & $\begin{array}{c}0.340 \\
0.00\end{array}$ & $\begin{array}{c}0.344 \\
0.00\end{array}$ & $\begin{array}{c}0.341 \\
0.00\end{array}$ & $\begin{array}{c}0.341 \\
0.00\end{array}$ & $\begin{array}{c}0.345 \\
0.00\end{array}$ & $\begin{array}{c}0.342 \\
0.00\end{array}$ \\
\hline NOQUALIF & $\begin{array}{c}-0.290 \\
0.00\end{array}$ & $\begin{array}{c}-0.290 \\
0.00\end{array}$ & $\begin{array}{c}-0.289 \\
0.00\end{array}$ & $\begin{array}{c}-0.286 \\
0.00\end{array}$ & $\begin{array}{c}-0.286 \\
0.00\end{array}$ & $\begin{array}{c}-0.284 \\
0.00\end{array}$ \\
\hline Industry-level varia & & & & & & \\
\hline FIRMNO & $\begin{array}{c}-0.008 \\
0.60\end{array}$ & $\begin{array}{c}-0.007 \\
0.71\end{array}$ & $\begin{array}{c}-0.006 \\
0.73\end{array}$ & $\begin{array}{c}-0.009 \\
0.57\end{array}$ & $\begin{array}{c}-0.007 \\
0.70\end{array}$ & $\begin{array}{c}-0.006 \\
0.72\end{array}$ \\
\hline WAGE & $\begin{array}{c}-0.005 \\
0.88\end{array}$ & $\begin{array}{c}-0.001 \\
0.98\end{array}$ & $\begin{array}{c}-0.009 \\
0.77\end{array}$ & $\begin{array}{c}-0.003 \\
0.93\end{array}$ & $\begin{array}{c}-0.001 \\
0.97\end{array}$ & $\begin{array}{c}-0.007 \\
0.81\end{array}$ \\
\hline$D D E M$ & $\begin{array}{c}-0.004 \\
0.44\end{array}$ & $\begin{array}{c}-0.002 \\
0.64\end{array}$ & $\begin{array}{c}-0.005 \\
0.40\end{array}$ & $\begin{array}{c}-0.004 \\
0.44\end{array}$ & $\begin{array}{c}-0.003 \\
0.64\end{array}$ & $\begin{array}{c}-0.005 \\
0.40\end{array}$ \\
\hline TRADE & $\begin{array}{c}0.122 \\
0.00\end{array}$ & $\begin{array}{c}0.038 \\
0.00\end{array}$ & $\begin{array}{c}0.123 \\
0.45\end{array}$ & $\begin{array}{c}0.121 \\
0.00\end{array}$ & $\begin{array}{c}0.037 \\
0.00\end{array}$ & $\begin{array}{c}0.129 \\
0.43\end{array}$ \\
\hline MIIT_1 & $\begin{array}{c}0.022 \\
0.40\end{array}$ & & & $\begin{array}{c}0.022 \\
0.39\end{array}$ & & \\
\hline$M I I T_{-} 3$ & & $\begin{array}{c}-0.029 \\
0.26\end{array}$ & & & $\begin{array}{c}-0.027 \\
0.28\end{array}$ & \\
\hline IIT & & & $\begin{array}{c}0.026 \\
0.24\end{array}$ & & & $\begin{array}{c}0.027 \\
0.22\end{array}$ \\
\hline$(M) I I T \times T R A D E$ & $\begin{array}{c}-0.132 \\
0.00\end{array}$ & $\begin{array}{c}-0.033 \\
0.13\end{array}$ & $\begin{array}{c}-0.112 \\
0.48\end{array}$ & $\begin{array}{c}-0.132 \\
0.00\end{array}$ & $\begin{array}{c}-0.031 \\
0.15\end{array}$ & $\begin{array}{c}-0.119 \\
0.46\end{array}$ \\
\hline Pseudo $R^{2}$ & 0.0278 & 0.0277 & 0.0277 & 0.0335 & 0.0335 & 0.0335 \\
\hline
\end{tabular}

Notes: 136,383 observations. Standardized (beta) coefficients for industry-level and continuous individual-level variables; raw coefficients divided by regression standard error for binary individual-level variables. $P$ values of significance tests based on industry-level clustered standard errors in italics. See text for variable definitions. Industry-level variables, BIGFIRM and PARTTIME lagged one period. All regressions include year dummies and region dummies (North, Yorkshire, North West, East Midlands, West Midlands, East Anglia, South West, South East, Wales, Scotland, Northern Ireland). 
focus on the specification that features interaction effects. Since the regressions include industry-specific explanatory variables, we use industry-level clustering for the computation of the error covariance matrix in order to avoid aggregation-induced downward bias of estimated standard errors (see Moulton 1990).

In Table 4, presenting the results on industry moves, we find the expected negative sign on the interaction between MIIT and trade exposure, and the main effects are no longer significantly different from zero. This is consistent with the SAH. When replacing the MIIT variable with the static IIT index, however, the interaction effect turns positive (albeit not statistically significant). Qualitatively, the SAH thus "survives" only with respect to the MIIT measure; and, if judged by statistical significance, only in terms of the three-year MIIT index. Furthermore, the coefficient sizes have shrunk considerably. The beta coefficient on the interaction term now corresponds to around 14 per cent of the beta coefficient on sector wages and to around 5 per cent of the coefficient on age. Hence, while we do pick up an effect of MIIT that is consistent with the SAH and statistically significant (not really surprising with 136,380 observations!), this effect seems to be of rather small magnitude.

What about the other explanatory variables? Our results are qualitatively very similar across specifications. Age, working in a large firm, working part time, being a home owner, having no formal qualifications and working in a high-wage industry all significantly reduce the probability of moving industry in any given year, while being married and highly educated increase it. The effect of age is linear, and neither gender nor nationality have a statistically significant influence on the probability of moving between industries.

Finally, Table 5 shows the corresponding estimates for occupation moves. Here too, we obtain consistently negative parameter estimates on the interaction terms with MIIT. Two of the four estimated interaction coefficients are statistically significant. The main effects, in turn, are not significantly different from zero- as expected. The IIT measure again performs less well, yielding statistically insignificant interaction coefficients in both specifications. Comparing the results of Table 5 to those of Table 3, we may conclude that controlling for worker-level heterogeneity in fact supports the SAH, as the estimation results are now more in line with the related priors. The magnitude of the estimated (M)IIT interaction effects, while being rather unstable across specifications, is about the same or larger than that of the main effect of trade exposure, and larger than the beta coefficients on all 
other industry-level explanatory variables. MIIT therefore does appear to have a statistically and economically significantly attenuating effect on interoccupational worker moves, other things equal. However, the MIIT effect is again considerably smaller than the effects of the main individual-level characteristics.

In terms of the control variables, two differences stand out in a comparison of the estimates in Table 5 with those of Table 4. Working in a large firm, while lowering the probability of moving sector, raise the probability of moving occupation. The interpretation is simple: workers in large firms move between jobs within those firms. The second notable difference is that sectoral wages, while highly significant in explaining inter-industry worker moves, turn insignificant in explaining inter-occupation moves. This is entirely plausible, since what matters for occupation moves are occupationspecific wages (which we do not observe), rather than industry-specific wages.

\section{Conclusions}

One criticism of previous research into the relationship between factor market adjustment and IIT has been the absence of a micro-econometric analysis of the labour market. Given that labour-market adjustment is central to the premise that IIT is less disruptive than inter-industry trade, it is argued that industry-level regressions may suffer from omitted variable bias stemming from the aggregation of individual worker moves to the sector level. To improve the efficiency of estimation and in order to control for within-industry heterogeneity we augment standard industry-level regressions with individual-level estimations. Data on individual workers in addition allow us to estimate the impact of IIT not only on the "sectoral distance" of worker moves but also on the "occupational distance".

The results of our industry-level regressions with sectoral moves as the dependent variable are consistent with the SAH and therefore confirm the results of prior research that has employed a range of different adjustment indicators. The results are less strong when the, arguably more relevant, occupational mobility variable is used to measure adjustment. When estimating the model on individual-level data, and thus controlling for worker characteristics, our findings are again consistent with the SAH: MIIT significantly reduces both the sectoral and the occupational "distance" of worker moves, and this effect is stronger the greater is the trade orientation of 
a particular industry. However, the magnitude of the impact of trade on a worker moves is small compared to that of other determinants. ${ }^{21}$

We ought to note that our measures of worker reallocation, whilst being broader than those used in comparable studies, still have their limitations. We are unable, for instance, to distinguish between voluntary and involuntary moves; and we can not account for moves into or out of unemployment. These are undoubtedly important dimensions of adjustment which it could be illuminating to explore explicitly in this context. Our definition of the "distance" of job moves would also deserve some additional scrutiny, as statistical classifications might not systematically map into the costs implied by worker moves across sectoral or occupational boundaries.

The estimated magnitudes of trade effects on worker moves in our data set are relatively small compared to the effects of some other explanatory variables. The United Kingdom, however, is a large country: its average import-to-expenditure ratio over the last decade has been the 6th smallest among the 30 countries of the OECD. ${ }^{22}$ Given that we find robust evidence in support of the SAH even for such a relatively closed economy, we conjecture that analysis of (M)IIT patterns should continue to be considered a worthwhile first-pass exercise to evaluate the adjustment implications of trade expansion.

\section{Appendix}

Table A1: Description of Variables

Industry-level variables:

IND2MOVE

IND3MOVE
Share of workers in base year moving to a different 2-digit SIC industry, relative to total number of base-year workers of relevant 3-digit SIC industry.

Share of workers in base year moving to a different 3-digit SIC industry, relative to total number of base-year workers of relevant 3-digit SIC industry.

21 Our findings are consistent with the results of broader studies of the effects of globalization on labour markets. For example, Slaughter (1999) in a survey of the effects of globalization on wages reports only a small effect of trade liberalization on increases in income inequality.

22 According to OECD statistics, the average share of imports in total final expenditure for the United Kingdom over the 1994-2003 period was 21.5 per cent. Only Japan, the United States, Australia, France and Italy had lower import penetration rates. 
OCC1MOVE Share of workers in base year moving to a different 1-digit SOC occupation, relative to total number of base-year workers of relevant 3-digit SIC industry.

OCC3MOVE Share of workers in base year moving to a different 3-digit SOC occupation, relative to total number of base-year workers of relevant 3-digit SIC industry.

FIRMNO Number of firms in an industry where an enterprise/business is defined as the smallest combination of legal units, which have a certain degree of autonomy within an enterprise group.

WAGE This is the addition of wages and salaries for Operatives and wages and salaries for Administrative, Technical and Clerical Employees.

DDEM Change in apparent consumption. Calculated as change in gross value added at factor cost, plus imports, minus exports.

TRADE Trade openness, measured as sectoral imports plus exports divided by value added.

MIIT_1 One-year MIIT index, calculated at SIC 3-digit level.

MIIT_3 Three-year MIIT index, calculated at SIC 3-digit level.

IIT Grubel and Lloyd (GL) index, calculated at SIC 3-digit level.

Individual-level variables:

\begin{tabular}{|c|c|}
\hline INDMOVDIST & $\begin{array}{l}\text { "Distance" of industry move: }=0 \text { if no move since base year, }=1 \text { if } \\
\text { moved firm, }=2 \text { if moved } 4 \text {-digit SIC, }=3 \text { if moved } 3 \text {-digit SIC, } \\
=4 \text { if moved } 2 \text {-digit SIC. }\end{array}$ \\
\hline FIRMMOVDUM & $\begin{array}{l}\text { "Distance" of occupation move: }=0 \text { if no move since base year, } \\
=1 \text { if moved } 3 \text {-digit SOC, }=2 \text { if moved 2-digit SOC, } \\
=3 \text { if moved } 1 \text {-digit SOC. }\end{array}$ \\
\hline OCCMOVDIST & Dummy: $=1$ if moved firm since base year. \\
\hline OCC3MOVDUM & Dummy: $=1$ if moved 3-digit SOC occupation since base year. \\
\hline$A G E$ & Years since birth. \\
\hline FEMALE & Dummy: $=1$ if female. \\
\hline BIGFIRM & Dummy: $=1$ if working in a firm with 25 employees or more. \\
\hline PARTTIME & Dummy: $=1$ if working part time (self defined). \\
\hline MARRIED & Dummy: $=1$ if married. \\
\hline HOMEOWNER & Dummy: $=1$ if housing owner-occupier. \\
\hline FOREIGNBORN & Dummy: = 1 if born outside the United Kingdom. \\
\hline HIGHEREDUC & Dummy: $=1$ if highest qualification is a third-level degree. \\
\hline NOQUALIF & Dummy: $=1$ if no formal educational qualifications. \\
\hline
\end{tabular}

Notes: Import (export) values are converted into constant prices using the UK import (export) price deflator. Wages and value added are converted into constant prices using the UK GDP deflator. For classifications of industries (SIC), occupations (SOC) and educational qualifications, see LFS user manual (www.data-archive.ac.uk/doc/4998/mrdoc/pdf/ classifications.pdf). For number of categories in SIC and SOC classifications, see notes to Table 1. 
Table A2: Summary Statistics

\begin{tabular}{|c|c|c|c|c|c|}
\hline & No. obs. & Mean & Std. dev. & Min. & Max. \\
\hline \multicolumn{6}{|l|}{ Industry-level variables: } \\
\hline $\begin{array}{l}\text { Share of 2-digit industry } \\
\text { movers (IND2MOVE) }\end{array}$ & 1,472 & 0.029 & 0.034 & 0 & 0.5 \\
\hline $\begin{array}{l}\text { Share of 3-digit industry } \\
\text { movers (IND3MOVE) }\end{array}$ & 1,472 & 0.034 & 0.036 & 0 & 0.5 \\
\hline $\begin{array}{l}\text { Share of 1-digit occupation } \\
\text { movers (OCC1MOVE) }\end{array}$ & 1,472 & 0.033 & 0.029 & 0 & 0.25 \\
\hline $\begin{array}{l}\text { Share of 3-digit occupation } \\
\text { movers (OCC3MOVE) }\end{array}$ & 1,472 & 0.051 & 0.039 & 0 & 0.4 \\
\hline FIRMNO & 1,327 & 1.029 & 3.563 & 0 & 67.52 \\
\hline TRADE & 1,324 & 5,003 & 17,013 & 0.12 & 475,652 \\
\hline WAGE & 1,329 & 15.06 & 5.753 & 0 & 53.86 \\
\hline$D D E M$ & 1,274 & -36.81 & 756.4 & $-20,343$ & 10,413 \\
\hline MIIT_1 $1 \times 100$ & 1,840 & 43.74 & 35.12 & 0 & 99.99 \\
\hline MIIT_3 $\times 100$ & 1,656 & 47.01 & 34.75 & 0 & 99.97 \\
\hline$I I T \times 100$ & 1,932 & 71.91 & 22.64 & 0 & 99.99 \\
\hline \multicolumn{6}{|l|}{ Individual-level variables: } \\
\hline $\begin{array}{l}\text { "Distance" of industry move } \\
\text { (INDMOVEDIST) }\end{array}$ & 181,850 & 0.133 & 0.591 & 0 & 3 \\
\hline $\begin{array}{l}\text { "Distance" of occupation } \\
\text { move (OCCMOVEDIST) }\end{array}$ & 181,850 & 0.051 & 0.220 & 0 & 1 \\
\hline$A G E$ & 181,850 & 39.09 & 11.98 & 17 & 64 \\
\hline FEMALE & 181,850 & 0.274 & 0.446 & 0 & 1 \\
\hline BIGFIRM & 181,850 & 0.780 & 0.414 & 0 & 1 \\
\hline PARTTIME & 181,821 & 0.063 & 0.242 & 0 & 1 \\
\hline MARRIED & 181,850 & 0.560 & 0.496 & 0 & 1 \\
\hline HOMEOWNER & 181,850 & 0.828 & 0.377 & 0 & 1 \\
\hline FOREIGNBORN & 181,850 & 0.061 & 0.239 & 0 & 1 \\
\hline HIGHEREDUC & 181,850 & 0.086 & 0.280 & 0 & 1 \\
\hline NOQUALIF & 181,850 & 0.350 & 0.477 & 0 & 1 \\
\hline
\end{tabular}

\section{References}

Andersson, L., O. Gustafsson, and L. Lundberg (2000). Structural Change, Competition and Job Turnover in the Swedish Manufacturing Industry 1964-96. Review of International Economics 8 (3): 566-582.

Azhar, A. K. M., and R. J. R. Elliott (2004). On the Measurement of TradeInduced Adjustment. Weltwirtschaftliches Archiv/Review of World Economics 139 (3): 419-439.

Bacchetta, M., and M. Jansen (2003). Adjusting to Trade Liberalisation: The Role of Policy, Institutions and WTO Disciplines. WTO Special Studies, No. 7. Geneva: WTO Publ. 
Balassa, B. (1966). Tariff Reductions and Trade in Manufactures among the Industrial Countries. American Economic Review 56 (1): 466-473.

Brecher, R. A., and E. U. Choudhri (1994). Pareto Gains from Trade Reconsidered: Compensating for Jobs Lost. Journal of International Economics 36 (3/4): 223238.

Brülhart, M. (1994). Marginal Intra-Industry Trade: Measurement and Relevance for the Pattern of Industrial Adjustment. Weltwirtschaftliches Archiv/Review of World Economics 130 (4): 600-613.

Brülhart, M. (2000). Dynamics of Intra-Industry Trade and Labor Adjustment. Review of International Economics 8 (3): 420-435.

Brülhart, M. (2002). Marginal Intra-Industry Trade: Towards a Measure of NonDisruptive Trade Expansion. In P. J. Lloyd and H.-H. Lee (eds.), Frontiers of Research on Intra-Industry Trade. Basingstoke: Palgrave Macmillan.

Brülhart, M., and R. J. R. Elliott (2002). Labour-Market Effects of Intra-Industry Trade: Evidence for the United Kingdom. Weltwirtschaftliches Archiv/Review of World Economics 138 (2): 207-228.

Davidson, C., and S. Matusz (2001). On Adjustment Costs. GEP Research Paper 2001/24. Centre for Research on Globalisation and Labour Markets, University of Nottingham.

Davidson, C. and S. Matusz (2004). Should Policy Makers Be Concerned about Adjustment Costs? In D. Mitra and A. Panagariya (eds.), The Political Economy of Trade, Aid and Foreign Investment Policies. Amsterdam: Elsevier.

De Melo, J., and D. Tarr (1990). Welfare Costs of U.S. Quotas in Textiles, Steel and Autos. Review of Economics and Statistics 72 (3): 489-497.

Dolton, P., and M. P. Kidd (1998). Job Changes, Occupational Mobility and Human Capital Acquisition: An Empirical Analysis. Bulletin of Economic Research 50 (4): 265-295.

Elliott, R. J. R., and J. K. Lindley (2006a). Trade Skills and Adjustment Costs: A Study of Intra-Sectoral Labour Mobility in the UK. Review of Development Economics 10 (1): 20-41.

Elliott, R. J. R., and J. K. Lindley (2006b). Skill Specificity and Labour Mobility: Occupational and Sectoral Dimensions. Manchester School 74 (3): 389-413.

Fallick, B. C. (1993). The Industrial Mobility of Displaced Workers. Journal of Labor Economics 11 (2): 302-323.

Greenaway, D., and C. Milner (1986). The Economics of Intra-Industry Trade. Oxford: Basil Blackwell.

Greenaway, D., M. Haynes, and C. Milner (2002). Adjustment, Employment Characteristics and Intra-Industry Trade. Weltwirtschaftliches Archiv/Review of World Economics 138 (2): 254-276.

Greenway, D., R. Upward, and P. Wright (2000). Sectoral Transformation and Labour Market Flows. Oxford Review of Economic Policy 16 (3): 57-75. 
Grubel, H. G., and P. J. Lloyd (1975). Intra-Industry Trade: The Theory and Measurement of International Trade with Differentiated Products. London: Macmillan.

Hamilton, C., and P. Kniest (1991). Trade Liberalization, Structural Adjustment and Intra-Industry Trade: A Note. Weltwirtschaftliches Archiv/Review of World Economics 127 (2): 356-367.

Haynes, M., R. Upward, and P. Wright (2000). Smooth and Sticky Adjustment: A Comparative Analysis of the US and UK. Review of International Economics 8 (3): 517-532.

Haynes, M., R. Upward, and P. Wright (2002). Estimating the Wage Costs of Interand Intra-Sectoral Adjustment. Weltwirtschaftliches Archiv/Review of World Economics 138 (2): 229-253.

Jacobson, L. S., R. I. LaLonde, and D. G. Sullivan (1993). Earnings Losses of Displaced Workers. American Economic Review 83 (4): 685-709.

Kletzer, L. G. (1996). The Role of Sector-Specific Skills in Post-Displacement Earnings. Industrial Relations 35 (4): 473-490.

Lovely, M., and D. Nelson (2000). On the Economic Relationship between Marginal Intra-Industry Trade and Labour Adjustment in a Division of Labour Model. Review of International Economics 8 (3): 436-447.

Lovely, M., and D. Nelson (2002). Intra-Industry Trade as an Indicator of Labor Market Adjustment. Weltwirtschaftliches Archiv/Review of World Economics 138 (2): 179-207.

Matusz, S., and D. Tarr (2000). Adjusting to Trade Policy Reform. In A. O. Krueger (ed.), Economic Policy Reform: The Second Stage. Chicago: University of Chicago Press.

Moulton, B. R. (1990). An Illustration of a Pitfall in Estimating the Effects of Aggregate Variables on Micro Units. Review of Economics and Statistics 72 (2): 223-338.

Neal, D. (1995). Industry-Specific Human Capital: Evidence from Displaced Workers. Journal of Labor Economics 13 (4): 653-677.

Shin, K. (1997). Inter- and Intrasectoral Shocks: Effects on the Unemployment Rate. Journal of Labor Economics 15 (2): 376-401.

Slaughter, M. (1999). Globalisation and Wages: A Tale of Two Perspectives. World Economy 22 (5): 609-630.

Takacs, W. E., and A. Winters (1991). Labour Market Adjustment and British Footwear Protection. Oxford Economic Papers 43 (3): 479-501. 